Aqueous nickel-nitrilotriacetate modified $\mathrm{Fe}_{3} \mathrm{O}_{4}-\mathrm{NH}_{3}{ }^{+}$nanoparticles for protein purification and cell targeting

This article has been downloaded from IOPscience. Please scroll down to see the full text article.

2006 Nanotechnology 174174

(http://iopscience.iop.org/0957-4484/17/16/030)

The Table of Contents and more related content is available

Download details:

IP Address: 140.112.113.225

The article was downloaded on 04/03/2009 at 04:37

Please note that terms and conditions apply. 


\title{
Aqueous nickel-nitrilotriacetate modified $\mathrm{Fe}_{3} \mathrm{O}_{4}-\mathrm{NH}_{3}^{+}$nanoparticles for protein purification and cell targeting
}

\author{
Dar-Bin Shieh ${ }^{1,6}$, Chia-Hao Su ${ }^{2,3}$, Fong-Yu Chang ${ }^{2}$, Ya-Na Wu ${ }^{1}$, \\ Wu-Chou Su${ }^{4}$, Jih Ru Hwu ${ }^{5}$, Jyh-Horng Chen ${ }^{3}$ and \\ Chen-Sheng Yeh ${ }^{2,6}$ \\ ${ }^{1}$ Institute of Oral Medicine and Molecular Medicine and Center for Micro/Nano Science and \\ Technology, National Cheng Kung University, Tainan 701, Taiwan \\ ${ }^{2}$ Department of Chemistry and Center for Micro/Nano Science and Technology, \\ National Cheng Kung University, Tainan 701, Taiwan \\ ${ }^{3}$ Institute of Biomedical Engineering and Department of Electrical Engineering and National \\ Taiwan University Center for Genomic Medicine, National Taiwan University, Taipei 106, \\ Taiwan \\ ${ }^{4}$ Department of Internal Medicine, National Cheng Kung University, Tainan 701, Taiwan \\ ${ }^{5}$ Department of Chemistry, National Tsing Hwa University, Hsinchu 300, Taiwan \\ E-mail: dshieh@mail.ncku.edu.tw and csyeh@mail.ncku.edu.tw
}

Received 4 April 2006, in final form 11 July 2006

Published 1 August 2006

Online at stacks.iop.org/Nano/17/4174

\begin{abstract}
A comprehensive totally aqueous phase synthesis of nickel-nitrilotriacetate (Ni-NTA) modified superparamagnetic $\mathrm{Fe}_{3} \mathrm{O}_{4}$ nanoparticles is presented. The $\mathrm{Fe}_{3} \mathrm{O}_{4}$-NTA-Ni nanoparticles are able to perform efficient and specific purification of 6-His tagged proteins from crude cell lysates, as evidenced by sodium dodecyl sulphate polyacrylamide gel electrophoresis (SDS-PAGE) and Western blot analysis. The average binding capacity, as demonstrated by streptopain $\left(M_{\mathrm{W}} 42 \mathrm{kDa}\right.$ ), is $0.23 \mathrm{mg} / \mathrm{mg}$ (protein/ $\mathrm{Fe}_{3} \mathrm{O}_{4}-\mathrm{NTA}-\mathrm{Ni}$ ). Considering the high affinity and specificity of the binding between hexahistidine motif and Ni-NTA, Ni-NTA modified nanoparticles could act as a module to carry 6-His tagged proteins on the particle surface with molecular orientation control, since only the 6-His domain could be attached. These modularly designed functional nanoparticles enhance cancer cell targeting, as supported by the in vitro receptor mediated targeting assay using RGD-4C-6-His fusion peptide. The nanoparticles show no significant hemolysis for human blood and could be investigated further for their in vivo functional imaging applications.
\end{abstract}

(Some figures in this article are in colour only in the electronic version)

\section{Introduction}

Nanoparticles have recently been investigated extensively for their potential biomedical applications in both diagnostics and therapeutics due to their distinct physical and chemical properties compared to the bulk status. In most applications, cross-linkage of the proteins onto the nanoparticles has

\footnotetext{
${ }^{6}$ Authors to whom any correspondence should be addressed.
}

utilized traditional chemical cross-linkers, which may result in unpredictable biomolecule orientation on the particle surfaces. Traditional chemical cross-linking strategies also fail to form a homogenous monolayer of ligands in most cases and thus increase the overall diameter and asymmetry of the nanoparticles. All these disadvantages lead to compromised binding and targeting efficiency.

Various metal ions have been identified to interact with a lot of different proteins [1-3]. Through a comprehensive 


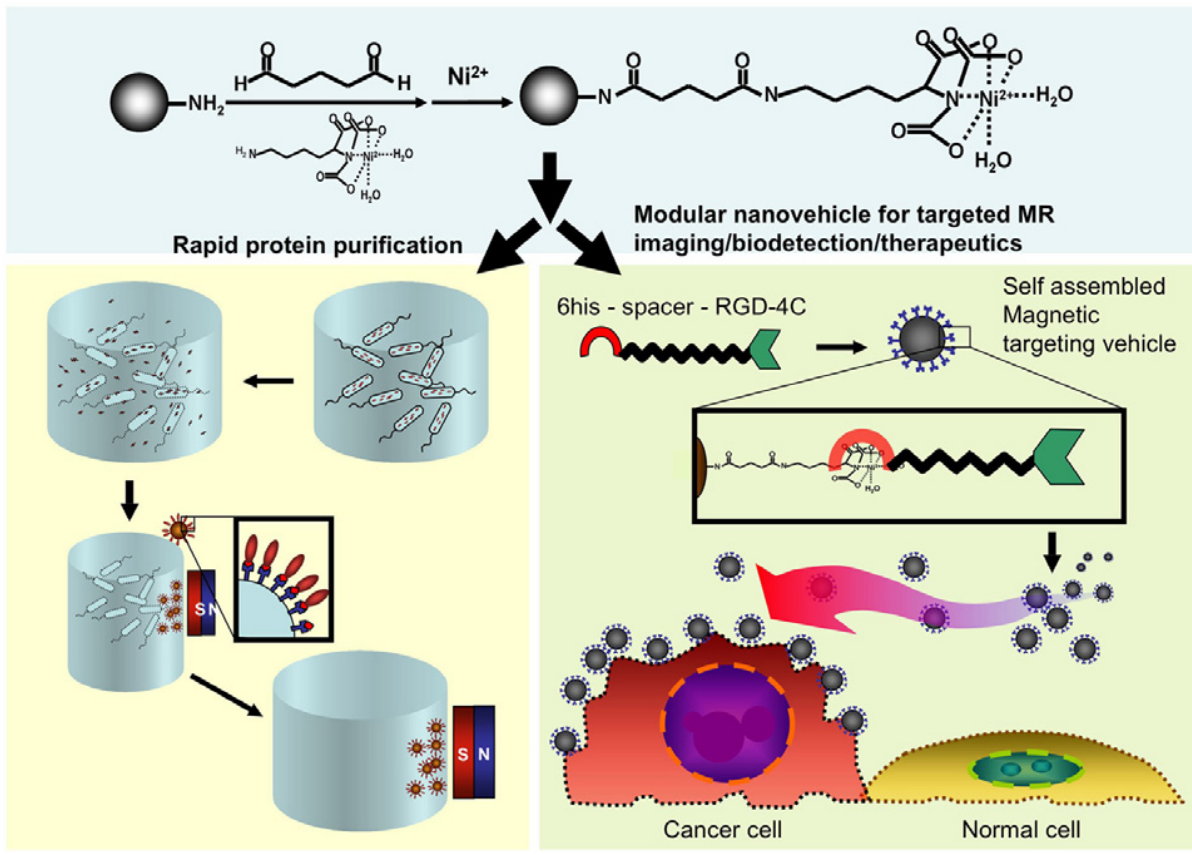

Scheme 1. Simplified process for rapid adsorption and elution of 6-His tagged proteins from bacteria or cells by $\mathrm{Fe}_{3} \mathrm{O}_{4}-\mathrm{NTA}-\mathrm{Ni}$ nanoparticles. The nanoparticles are mixed with bacteria lysate and subject to further magnetic force separation and washing to remove the remnants and the non-specific bindings. The target proteins are recovered by elution buffer containing imidazole as the competitor and the nanoparticles could be reused after re-activation. The specific affinity between 6-His tag and Ni-NTA on the nanoparticles also serves as a module for rapid orientation controlled bioconjugation for 6-His tagged functional peptides. As a demonstration, we have self-assembled RGD-4C-6-His fusion peptide on the Ni-NTA-nanoparticles which presents integrin expression specific targeting to the oral cancer cells compared to the normal oral keratinocytes.

coordination, electron-donor atoms such as $\mathrm{S}, \mathrm{O}$ or $\mathrm{N}$ in the amino acid residues may interact with metal ions with high affinity $[4,5]$. Amino acids containing electron donors include aspartate, glutamate, cysteine or histidine. Among these, histidine is a ubiquitous amino acid usually present in the metal-binding regions of metalloenzymes $[6,7]$. Threedimensional (3D) structure analysis of many metalloproteins revealed that histidine side chains usually folded into a favourable conformation of stable metal-binding pockets [8]. Although histidine may also be present on the exposed surface of many non-modified proteins, the consecutive 6-8 histidine residues automatically fold into appropriate conformation with extremely high affinity for nickel or cobalt ions compared to the single exposed histidine residue. As a result, poly-histidine residue has been one of the most widely used functional tags in molecular cloning and protein chemistry. Besides, only a few proteins in the nature have a native consecutive 6 histidine domain in their structures [9]. These advantages not only enable specific isolation of the desired peptides tagged with genetically engineered 6-histidine through a metal ion column chromatography, but also may potentially assist protein immobilization on a solid-phase support with the correct orientation for future molecule-molecule interaction based diagnostic detections or therapeutic applications [10-13].

Nitrilotriacetic acid (NTA) is a tricarboxylic acid monoamino chelator that could form a stable complex with transition metal ions such as $\mathrm{Ni}^{2+}, \mathrm{Zn}^{2+}$ and $\mathrm{Co}^{2+}$ [14]. In the 3D structural conformation, two vacant coordination sites on the metal ion are exposed, which enable stable and strong interaction with the electron-donor containing pouch in the poly-histidine sequences [8]. Of the metal ions, $\mathrm{Ni}^{2+}$ is recognized to be the best one in most applications, although recent studies have reported that the cobalt ion provides improved specificity for the 6-His tagged peptides compared to the nickel ion [15]. The correct orientation of biomolecules and the preservation of their functionality have been one of the most critical challenges for the development of nanoparticlebased biomedical applications [10, 11, 16-19]. An antibody or ligand library may thus take advantage of a self-assembly monolayer (SAM) on the particle's surface to enhance their overall performance and ease of practical usage and storage. Interestingly, there is no report on the direct synthesis of nanoscale aqueous $\mathrm{Fe}_{3} \mathrm{O}_{4}$-NTA-Ni particles targeting Histagged proteins so far.

Recently, we synthesized $\mathrm{Fe}_{3} \mathrm{O}_{4}-\mathrm{NH}_{3}^{+}$nanoparticles with an average diameter of $6.2 \pm 1.1 \mathrm{~nm}$ and demonstrated that their trypsin conjugates preserved functional activity well $[20,21]$. The aqueous $\mathrm{Fe}_{3} \mathrm{O}_{4}-\mathrm{NH}_{3}^{+}$nanoparticles also displayed excellent in vitro biocompatibility and significantly reduced water proton relaxation times for both $T_{1}$ and $T_{2}$. Significantly reduced $T_{2}$ and $T_{2}^{*}$-weighted signal intensity were observed in a $1.5 \mathrm{~T}$ clinical magnetic resonance (MR) imager using phantom arrays. A fast response and prolonged inverse contrast effect lasting for more than 1 week was observed in $T_{2}^{*}$-weighted MRI sequence of the liver of the test animal.

In this study, we provide a comprehensive and straightforward approach for the totally aqueous phase synthesis of $N^{\alpha}, N^{\alpha}$-Bis(carboxymethyl)-L-lysine (nitrilotriacetic acid; NTA) surface modified superparamagnetic $\mathrm{Fe}_{3} \mathrm{O}_{4}$ nanoparticles (scheme 1). Their efficiency and specificity in protein purification were evaluated. Hexahistidine-engineered RGD4C 
peptide was synthesized to evaluate the efficiency of the selective targeting of cancer cells expressing $\alpha \mathrm{v} \beta 3$ and $\alpha \mathrm{v} \beta 5$ integrin, compared to the identical nanoparticles modified by random chemical crosslinking (scheme 1). The hemolysis assay was performed using human whole blood as an initial step to validate their potential future in vivo applications as molecular imaging agents or targeted hyperthermia and/or chemotherapeutic agents.

\section{Experimental section}

\subsection{Chemicals and characterization}

Bromoacetic acid and $N^{\varepsilon}$-benzyloxycarbonyl-L-lysine were purchased from Fluka; $10 \% \mathrm{Pd} / \mathrm{C}$ was purchased from Lancaster; Coomassie Brilliant Blue G-250 was purchased from Bio-Rad Laboratories Inc.; PVDF membranes were purchased from PerkinElmer Inc., Boston, MA, USA; the Renaissance Western Blot Chemiluminescence Reagents were purchased from PerkinElmer Inc., Boston, MA, USA; the Scientific Imaging films were purchased from Eastman Kodak, Rochester, NY, USA $;{ }^{1} \mathrm{H},{ }^{13} \mathrm{C}$ NMR spectra were obtained on a $300 \mathrm{MHz}$ Bruker Avance300. The thermogravimetric analysis (TGA) was obtained on a Shimadzu PA-50WSI analyser. The spectrophotometric measurements of proteins were obtained on a Dynex Technologies MRX II. The spectrophotometric measurements of hemocompatibility were obtained on a Coulter Gen-S analyser.

\section{2. $\mathrm{Fe}_{3} \mathrm{O}_{4}-\mathrm{NH}_{3}^{+}$nanoparticle preparation}

For preparing water-soluble and dispersed $\mathrm{Fe}_{3} \mathrm{O}_{4}$ nanoparticles, two-stage additions of protective agent and chemical coprecipitation were employed in the process $[20,21]$. The $1 \mathrm{M}$ ferric chloride hexahydrate $\left(\mathrm{FeCl}_{3} \cdot 6 \mathrm{H}_{2} \mathrm{O}>99 \%\right)$ and $2 \mathrm{M}$ ferrous chloride tetrahydrate $\left(\mathrm{FeCl}_{2} \cdot 4 \mathrm{H}_{2} \mathrm{O}>99 \%\right)$ were prepared by dissolving iron salts in $2 \mathrm{M} \mathrm{HCl}$ solutions, respectively. Two solutions containing $\mathrm{Fe}^{\mathrm{II}}$ and $\mathrm{Fe}^{\mathrm{III}}$ at a predetermined mole ratio $\left(\mathrm{Fe}^{\mathrm{III}} / \mathrm{Fe}^{\mathrm{II}}=2\right)$ were mixed, followed by the addition of organic acid as adherent. Subsequently, the $\mathrm{pH}$ of the solution was carefully adjusted to over 10 and an appropriate amount of adherent was added to achieve complete coating of the particle surface with the $-\mathrm{NH}_{3}^{+}$group, resulting in the $\mathrm{Fe}_{3} \mathrm{O}_{4}$ nanoparticle dispersion appearing as a black colour.

\subsection{Synthesis of $N^{\alpha}, N^{\alpha}$ - Bis(carboxymethyl)- $N^{\varepsilon}$ - (benzyloxycarbonyl)-L-lysine $\left(N^{\varepsilon}-Z-N T A\right)$}

Bromoacetic acid (0.52 g, $3.75 \mathrm{mmol})$ was dissolved in $\mathrm{NaOH}$ solution $(3 \mathrm{ml}, 5 \mathrm{~N})$ and cooled at $0{ }^{\circ} \mathrm{C} . N^{\varepsilon}$-benzyloxycarbonylL-lysine $(0.42 \mathrm{~g}, 1.5 \mathrm{mmol})$ in $5 \mathrm{~N} \mathrm{NaOH}$ solution $(3 \mathrm{ml})$ added dropwise at $0{ }^{\circ} \mathrm{C}$ while stirring [22]. After $2 \mathrm{~h}$, the ice bath was removed and the mixture was refluxed overnight. The temperature of the mixture was cooled down, followed by adding a $5 \mathrm{~N} \mathrm{HCl}$ solution $(6 \mathrm{ml})$ with additional $0.5 \mathrm{~h}$ stir. The product was collected by filtration and washed by a $1 \mathrm{~N} \mathrm{HCl}$ solution. $N^{\alpha}, N^{\alpha}$-Bis(carboxymethyl)$N^{\varepsilon}$-(benzyloxycarbonyl)-L-lysine $\left(N^{\varepsilon}\right.$-Z-NTA, $\left.0.44 \mathrm{~g}\right)$ was obtained as a white solid with a yield of $78 \%$. ${ }^{1} \mathrm{H}-\mathrm{NMR}$ was performed with the following characteristics: $(300 \mathrm{MHz}$,
d6-DMSO) $\delta=1.2-1.8\left(\mathrm{~m}, 6 \mathrm{H}, \mathrm{CHCH}_{2} \mathrm{CH}_{2} \mathrm{CH}_{2} \mathrm{CH}_{2} \mathrm{NH}\right)$, $\delta=2.9\left(\mathrm{q}, 2 \mathrm{H}, J=5.9 \mathrm{~Hz}, \mathrm{NHCH}_{2} \mathrm{CH}_{2}\right), \delta=3.3(\mathrm{t}$, $\left.1 \mathrm{H}, J=7.2 \mathrm{~Hz}, \mathrm{NCHCH}_{2}\right), \delta=3.48(\mathrm{dd}, 4 \mathrm{H}, J=21.9$, $\left.23.3 \mathrm{~Hz}, \mathrm{NCH}_{2} \mathrm{COOH}\right), \delta=4.9\left(\mathrm{~s}, 2 \mathrm{H}, \mathrm{C}_{6} \mathrm{H}_{5} \mathrm{CH}_{2}\right), \delta=7.2$ (t, $1 \mathrm{H}, J=5.4 \mathrm{~Hz}, \mathrm{OCONH}), \delta=7.3\left(\mathrm{~m}, 5 \mathrm{H}, \mathrm{C}_{6} \mathrm{H}_{5} \mathrm{CH}_{2}\right)$; ${ }^{13} \mathrm{C}-\mathrm{NMR}(75 \mathrm{MHz}, \mathrm{d} 6-\mathrm{DMSO}) \delta=173.5(\mathrm{CHCOOH})$, $\delta=172.8\left(\mathrm{CH}_{2} \mathrm{COOH}\right), \delta=156.1(\mathrm{OCONH}), \delta=137.3$ (phenyl-C1), $\delta=128.4$ (phenyl-C2, C3), $\delta=127.8$ (phenylC4) $\delta=65.1\left(\mathrm{NCH}_{2} \mathrm{COOH}\right), \delta=64.5(\mathrm{NCHCOOH})$, $\delta=53.4\left(\mathrm{OCONHCH}_{2}\right), \delta=29.2\left(\mathrm{NCHCH}_{2}\right), \delta=29.1$ $\left(\mathrm{NHCH}_{2} \mathrm{CH}_{2}\right), \delta=23.0\left(\mathrm{NCHCH}_{2} \mathrm{CH}_{2} \mathrm{CH}_{2} \mathrm{CH}_{2} \mathrm{NH}\right)$.

\subsection{Synthesis of $N^{\alpha}, N^{\alpha}$-Bis(carboxymethyl)-L-lysine(NTA)}

$N^{\alpha}, N^{\alpha}$-Bis(carboxymethyl)- $N^{\varepsilon}$-(benzyloxycarbonyl)-L-lysine (1.09 g, $2.75 \mathrm{mmol}$ ) was dissolved in $\mathrm{MeOH} / \mathrm{H}_{2} \mathrm{O}$ solution $\left(\mathrm{MeOH} / \mathrm{H}_{2} \mathrm{O}=20 / 1,40 \mathrm{ml}\right)$ [22]. After the addition of a spatula tip of $\mathrm{Pd} / \mathrm{C}(10 \%)$, the mixture was hydrogenated at room temperature. The reaction was completed after $3 \mathrm{~h}$, as monitored by TLC $\left(\mathrm{MeCN} / \mathrm{H}_{2} \mathrm{O}=4 / 1\right)$ and visualized with UV and $\mathrm{I}_{2}$. The catalyst was filtered off and the product was crystallized at $0{ }^{\circ} \mathrm{C}$ within 2 days. The crystals $(0.617 \mathrm{~g})$ were collected and dried in vacuum. The final yield was calculated to be $85 \%$. ${ }^{1} \mathrm{H}-\mathrm{NMR}$ was performed with the following characteristics: $\left(300 \mathrm{MHz}, \mathrm{D}_{2} \mathrm{O}\right) \delta=1.3-2.0(\mathrm{~m}$, $\left.6 \mathrm{H}, \mathrm{H}_{2} \mathrm{NCH}_{2} \mathrm{CH}_{2} \mathrm{CH}_{2} \mathrm{CH}_{2} \mathrm{CH}\right), \delta=2.9\left(\mathrm{t}, 2 \mathrm{H}, \mathrm{NCHCH}_{2}\right)$, $\delta=3.8\left(\mathrm{~s}, 4 \mathrm{H}, \mathrm{HCNCH}_{2} \mathrm{COOH}\right) ;{ }^{13} \mathrm{C}-\mathrm{NMR}(75 \mathrm{MHz}$, $\left.\mathrm{D}_{2} \mathrm{O}\right) \delta=171.5(\mathrm{NCHCOOH}), \delta=169.7\left(\mathrm{NCH}_{2} \mathrm{COOH}\right)$, $\delta=67.2\left(\mathrm{NCH}_{2} \mathrm{COOH}\right), \delta=54.7\left(\mathrm{NCHCH}_{2}\right), \delta=$ $38.6\left(\mathrm{H}_{2} \mathrm{NCH}_{2} \mathrm{CH}_{2}\right), \delta=26.0\left(\mathrm{NCHCH}_{2}\right), \delta=25.9$ $\left(\mathrm{NHCH}_{2} \mathrm{CH}_{2}\right), \delta=22.5\left(\mathrm{NCHCH}_{2} \mathrm{CH}_{2} \mathrm{CH}_{2} \mathrm{CH}_{2} \mathrm{NH}\right)$.

\section{5. $\mathrm{Fe}_{3} \mathrm{O}_{4}$ nanoparticles conjugated with $\mathrm{NTA}$ and $\mathrm{Ni}^{2+}$ ions}

One millilitre of $0.1 \mu \mathrm{M}$ (particle concentration) $\mathrm{Fe}_{3} \mathrm{O}_{4}$ nanoparticles with $-\mathrm{NH}_{3}$ modification was added to $1 \mathrm{ml}$ of $0.2 \mathrm{M} N^{\alpha}, N^{\alpha}$-Bis(carboxymethyl)-L-lysine (NTA) and $400 \mu \mathrm{l}$ of $55 \%(\mathrm{w} / \mathrm{w})$ glutaraldehyde at room temperature for stirring for $8 \mathrm{~h}$. After conjugating $\mathrm{Fe}_{3} \mathrm{O}_{4}$ nanoparticles with NTA, $2 \mathrm{ml}$ of $1.0 \mathrm{M} \mathrm{NiSO}_{4}$ was added and the mixture was stirred at room temperature for different time periods. When the incubation was completed, the mixture was centrifuged at $13000 \mathrm{rpm}$ for $5 \mathrm{~min}$ and the supernatant was removed. The resulting precipitates $\left(\mathrm{Fe}_{3} \mathrm{O}_{4}-\mathrm{NTA}-\mathrm{Ni}\right)$ were redispersed in $2 \mathrm{ml} \mathrm{H}_{2} \mathrm{O}$ and centrifuged at $13000 \mathrm{rpm}$ for $5 \mathrm{~min}$ to remove the excess $\mathrm{Ni}^{2+}$ ions. The $\mathrm{Fe}_{3} \mathrm{O}_{4}-\mathrm{NTA}-\mathrm{Ni}$ nanoparticles were further redispersed in $1 \mathrm{ml} \mathrm{H}_{2} \mathrm{O}$ and analysed by atomic absorption spectroscopy (AA) to measure the ratio of $\mathrm{Ni}^{2+}$ ion to $\mathrm{Fe}_{3} \mathrm{O}_{4}$ NTA nanoparticles as a function of incubation period between $\mathrm{NiSO}_{4}$ and $\mathrm{NTA}-\mathrm{Fe}_{3} \mathrm{O}_{4}$.

\subsection{The quantity of NTA molecules on $\mathrm{Fe}_{3} \mathrm{O}_{4}$ nanoparticles}

The quantity of NTA molecules on the $\mathrm{Fe}_{3} \mathrm{O}_{4}$ nanoparticle's surface was measured and evaluated by thermogravimetric analysis (TGA). The experiments were carried out using $14.79 \mathrm{mg}$ of $\mathrm{Fe}_{3} \mathrm{O}_{4}$-NTA sample, which was placed in an open Pt pan. Compressed air flowing at a rate of $20 \mathrm{ml} \mathrm{min}^{-1}$ served as the purge gas and the sample temperature was raised from 26.8 to $600^{\circ} \mathrm{C}$ at a rate of $10^{\circ} \mathrm{C} \mathrm{min}{ }^{-1}$. Based on the loss of sample weight, we can calculate the quantity of NTA molecules conjugated with the $\mathrm{Fe}_{3} \mathrm{O}_{4}$ nanoparticles. 
Aqueous nickel-nitrilotriacetate modified $\mathrm{Fe}_{3} \mathrm{O}_{4}-\mathrm{NH}_{3}^{+}$nanoparticles

\subsection{Determination of the binding capacity for 6-His tagged} proteins

The binding capacity of the newly synthesized $\mathrm{Fe}_{3} \mathrm{O}_{4}$-NTA$\mathrm{Ni}$ nanoparticles to 6-His tagged proteins was evaluated by using purified V344A mutant streptopain $\left(M_{\mathrm{W}} 42 \mathrm{kDa}\right)$ with 6-His tag on the N-terminus [23]. For the protein binding assay, the purified streptopain solutions (350.86 $\mu \mathrm{g} \mathrm{ml}^{-1}$ ) varied from 0 to $390 \mu \mathrm{l}$ were mixed with $10 \mu \mathrm{l}$ of $\mathrm{Fe}_{3} \mathrm{O}_{4}$ NTA-Ni nanoparticles $\left(32 \mathrm{mg} \mathrm{ml}^{-1}\right)$, then added to the binding buffer to a total volume of $400 \mu$ l. Subsequently, the reaction mixtures were incubated at $4{ }^{\circ} \mathrm{C}$ for $20 \mathrm{~min}$. The nanoparticles with adsorbed streptopain were isolated by a small magnet. The nanoparticles were washed with $100 \mu \mathrm{l}$ wash buffer (200 mM NaH${ }_{2} \mathrm{PO}_{4}, 500 \mathrm{mM} \mathrm{NaCl}, \mathrm{pH}$ 7.4) to eliminate non-specific bindings. The flow-through solution and washing solutions were collected to detect the non-binding proteins and to calculate the quantity of the binding proteins on $\mathrm{Fe}_{3} \mathrm{O}_{4}$ NTA-Ni. For the quantification of the purified streptopain, Coomassie Brilliant Blue G-250 (Bio-Rad Laboratories Inc.) was applied as the dye to visualize the proteins. The binding capacity was determined by spectrophotometric measurement of the optical adsorption $(590 \mathrm{~nm})$ of each fraction of the collected solutions and converted into protein concentrations according to the standard curve using BSA as the reference protein.

The effect of elution buffers to the final yield of protein purification was evaluated as a function of imidazole concentration. The protein binding and wash procedure were performed as the aforementioned text except for the ingredients of the final elution buffers, which contained different concentrations of imidazole. The final yield of the target protein was evaluated by spectrophotometric analysis at $590 \mathrm{~nm}$.

\subsection{Purification of 6-His tagged recombinant proteins from bacteria lysate}

The E. coli BL21 (DE3) transfected with pET21a containing a full-length mutant streptopain cDNA V334A with 6-his tagged on the $\mathrm{N}$-terminal end [23]. Cells were grown at $37^{\circ} \mathrm{C}$ for $6-$ $8 \mathrm{~h}$ in LB medium ( 11 of $10 \mathrm{~g}$ of Bacto-Trypton, $5 \mathrm{~g}$ of Bactoyeast extract, and $10 \mathrm{~g}$ of $\mathrm{NaCl}$ adjusted to $\mathrm{pH} 7.2$ with $3 \mathrm{~N}$ $\mathrm{NaOH})$. A final bacteria concentration at $A_{600}=0.5-1.0$ was used to induce recombinant gene expression by the addition of isopropyl-1-thio- $\beta$-D-glactopyranoside (IPTG) to a final concentration of $1 \mathrm{mM}$ and further incubated for additional $24 \mathrm{~h}$ at $37^{\circ} \mathrm{C}$. The bacteria was collected by centrifugation and lysed by liquid shear with a French press to obtain the final lysate on ice, and then the lysate was centrifuged (13000 rpm, for $10 \mathrm{~min}$ at $4^{\circ} \mathrm{C}$ ) to remove the crude precipitates before being subject to further protein purification.

To evaluate the efficiency of protein purification utilizing newly synthesized NTA-Ni modified magnetite nanoparticles through magnetic force manipulation, the supernatant of cell lysate was mixed with a buffer solution containing the $\mathrm{Fe}_{3} \mathrm{O}_{4}$ NTA-Ni nanoparticles at a concentration of $32 \mathrm{mg} \mathrm{ml}^{-1}$ followed by a magnetic separation. The protein purification was performed as described earlier. The derived proteins in each fraction were visualized on a SDS-PAGE after electrophoresis and Coomassie Brilliant Blue G-250 staining.

\subsection{Western blot analysis}

To evaluate the specificity and degradation in the elution process of the target protein, Western blot analysis was performed. $20 \mu \mathrm{l}$ of each collected fraction was loaded on a $15 \%$ SDS-polyacrylamide gel and separated by electrophoresis, then transferred to a PVDF membrane (PerkinElmer Inc., Boston, MA, USA). The streptopain was detected with a horse radish peroxidase conjugated monoclonal antibody against 6-His-tag of the fusion protein (Chemicon International Inc., Temecular, CA, USA). After incubation, the signal was detected by chemiluminescence assay using the Renaissance Western Blot Chemiluminescence Reagent (PerkinElmer, Inc., Boston, MA, USA) and Scientific Imaging film (Eastman Kodak, Rochester, NY, USA).

\subsection{Hemocompatibility of $\mathrm{Fe}_{3} \mathrm{O}_{4}-\mathrm{NTA}-\mathrm{Ni}$ nanoparticles}

Spectrophotometric measurement for the presence of hemoglobin in human plasma released from ruptured red blood cells after exposure to the nanoparticles served as an index for their hemocompatibility. The fresh human whole blood was obtained from a healthy donor with informed consent, following guidelines for studies using human tissues. $\mathrm{Fe}_{3} \mathrm{O}_{4}-\mathrm{NTA}-\mathrm{Ni}$ nanoparticles were added to $1 \mathrm{ml}$ of human whole blood containing $12 \mathrm{IU}$ sodium heparin to final particle concentrations of $0,10^{-10}, 10^{-9}, 10^{-8}, 10^{-7}, 10^{-6}$, and $10^{-5} \mathrm{M}$. The solutions were gently mixed on a rotary shaker for $4 \mathrm{~h}$ at $37^{\circ} \mathrm{C}$ followed by centrifugation at $1200 \mathrm{rpm}$ for $10 \mathrm{~min}$ to remove the red blood cells and another centrifugation at $13000 \mathrm{rpm}$ for $30 \mathrm{~min}$ to eliminate the nanoparticles. The hemoglobin concentration in the supernatant was then determined by spectrophotometric analysis $(454 / 528 \mathrm{~nm})$ in a Coulter Gen-S analyser (Beckman Inc, USA).

As a comparative study, we also evaluated the relative hemolysis of the nanoparticles at different concentrations compared to the positive and the negative control. Fresh human blood was collected and diluted with normal saline solution $(8 \mathrm{ml}$ blood $+10 \mathrm{ml}$ normal saline). The hemolysis assay was performed by adding $20 \mu \mathrm{l}$ of the diluted blood to $1 \mathrm{ml}$ of $0.1 \%$ sodium carbonate solution as a positive control or $1 \mathrm{ml}$ of normal saline as a negative control or $1 \mathrm{ml}$ of the experimental groups containing different concentrations of the nanoparticles, ranging from $10^{-6}-10^{-10} \mathrm{M}$. After incubation, all the test tubes were centrifuged for $5 \mathrm{~min}$ at $3000 \mathrm{rpm}$ and the supernatant was transferred to a cuvette for spectroscopic analysis at a wavelength of $545 \mathrm{~nm}$, and the percentage of hemolysis was calculated by:

\section{Percentage hemolysis}

$$
=[\mathrm{OD}(\text { test })-\mathrm{OD}(\text { negative control }) \times 100] /
$$

[OD (positive control) - OD (negative control)]

where $\mathrm{OD}=$ the optical density at $545 \mathrm{~nm}$.

The percentage of hemolysis was calculated based on the average of three replicates. High hemocompatibility was given for samples with $<5 \%$ hemolysis, hemocompatible for samples within $10 \%$ hemolysis, and non-hemocompatible for $>20 \%$ hemolysis. 


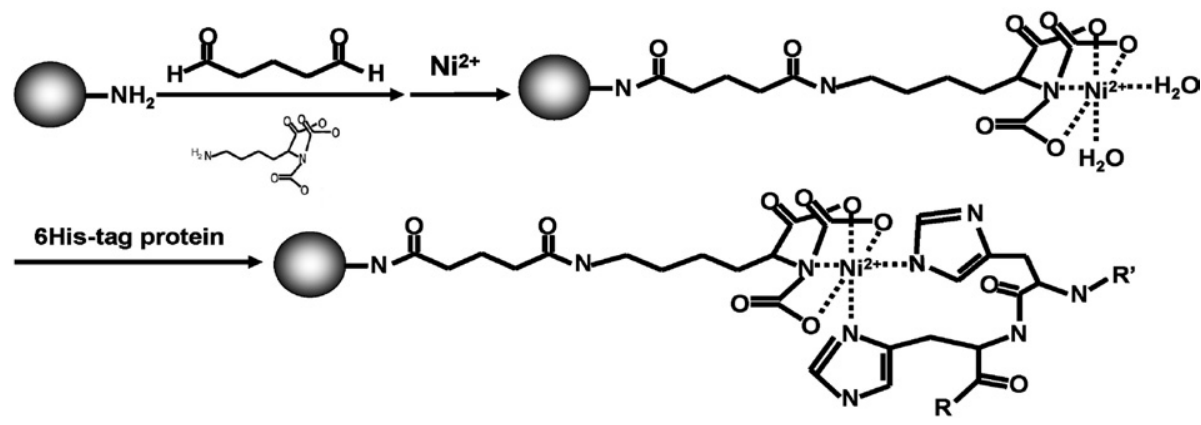

Scheme 2. The surface modification of the $\mathrm{Fe}_{3} \mathrm{O}_{4}-\mathrm{NTA}-\mathrm{Ni}$ nanoparticle complex. A covalent bond is established between the primary amine of the nanoparticle surface and glutaraldehyde. The NTA covalently attaches onto the nanoparticle with a projected carboxyl group to chelate the nickel ion and leaves two vacant sites for affinity binding to 6-His tagged proteins.

\subsection{Preparation of RGD-4C-6-His magnetite nanoparticle conjugate and in vitro targeting analysis}

The RGD-4C-6-His peptide (H-Ala-Cys-Asp-Cys-Arg-GlyAsp-Cys-Phe-Cys-Gly-Gly-Gly-Gly-Gly-Gly-His-His-HisHis-His-His-OH, disulfide bridge: 2-10 and 4-8) was synthesized (Genesis Biotech Inc., Taiwan) for the evaluation of cell targeting. The resulting $\mathrm{Fe}_{3} \mathrm{O}_{4}$-NTA-Ni reserves two binding sites for the interaction with the poly-histidine structure of the fusion peptide (scheme 2). Two vacant coordination sites on the nickel ions enable strong complexing with the electrondonor containing pouch in the poly-histidine sequences. For conjugation of the RGD-4C-6-His peptide to the nanoparticle surface, the peptide was incubated with the particle at room temperature for 5 min under gentle agitation in a 10:1 peptideto-nanoparticle molar ratio, then subjected to magnetic separation and washing to remove non-binding peptides. The particles were re-suspended in phosphate buffer containing $10 \%$ goat serum and sonication in a water bath for $10 \mathrm{~min}$ before the experimental targeting. Oral cancer cell line HCDB-1 [24], which expresses a high level of $\alpha \mathrm{v} \beta 3$ integrin and normal oral keratinocytes (HNOK) with lower expression level, served as the model system and the negative control for a selective targeting experiment, respectively. The cells were grown in chamber slides (Nalge Nunc International Corp., IL, USA) in their respective culture media at $37{ }^{\circ} \mathrm{C}$ in humidified air containing $5 \% \mathrm{CO}_{2}$. The RGD-4C-6-His magnetite nanoparticles were then co-incubated with cells cultured on the chamber slides for $30 \mathrm{~min}$ at $4{ }^{\circ} \mathrm{C}$ with gentle shaking. The medium was removed and washed twice with PBS, followed by fixing with $4 \%$ glutaldehyde. To visualize the nanoparticle aggregates caused by affinity binding between RGD-4C and integrin on the target cells, Pearl's iron staining was performed and the results were photographed under an optical microscopy (Olympus, BH-2).

\subsection{Instrumentation}

Electron micrographs of the $\mathrm{Fe}_{3} \mathrm{O}_{4}$ dispersions were carried out using a drop of the sample onto a copper mesh coated with an amorphous carbon film, and then dried in a vacuum desiccator. The prepared samples were studied in a transmission electron microscope (JEOL JEM-1200-EX). Thermogravimetric analysis was carried out under a stream of nitrogen, at a heating rate of $10^{\circ} \mathrm{C} \mathrm{min}^{-1}$, using a TA Q50 Thermogravimetric analyser (TA Instruments Inc.)

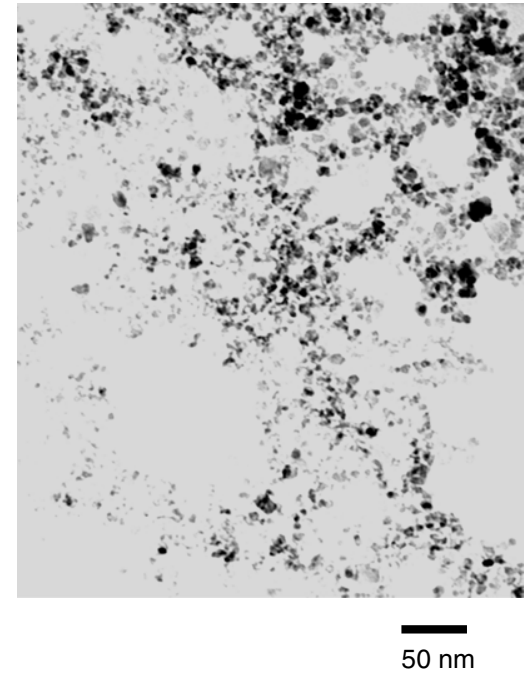

Figure 1. TEM image of $\mathrm{Fe}_{3} \mathrm{O}_{4}$ nanoparticles conjugated with NTA.

\section{Results and discussion}

\subsection{Preparation of $\mathrm{Fe}_{3} \mathrm{O}_{4}-\mathrm{NH}_{3}^{+}$modified with $\mathrm{NTA}$ and $\mathrm{Ni}^{2+}$} ion

We have recently reported the aqueous synthesis of $\mathrm{Fe}_{3} \mathrm{O}_{4}-$ $\mathrm{NH}_{3}^{+}$nanoparticles $(6.2 \pm 1.1 \mathrm{~nm})$ and applied enzyme bio-conjugation, such as trypsin [20, 21]. This strategy for enzyme immobilization could preserve the enzyme activity. Furthermore, we demonstrated the negative contrast effect for MR imaging applications and their biocompatibility [21]. Herein, the $\mathrm{Fe}_{3} \mathrm{O}_{4}$ nanoparticle surface with amine functional groups is further covalently crosslinked to NTA by glutaraldehyde (scheme 2).

Scheme 2 illustrates the surface chemistry of the newly synthesized nanoparticles. The NTA was covalently attached to the amino groups on the nanoparticles by using glutaraldehyde as the linker. Figure 1 displays the TEM image of as-prepared $\mathrm{Fe}_{3} \mathrm{O}_{4}$-NTA nanoparticles with some degree of aggregation. The nickel ions were chelated by NTA molecules immobilized on the nanoparticle surface. The resulting $\mathrm{Fe}_{3} \mathrm{O}_{4}-$ NTA-Ni reserves two binding sites for the interaction with the poly-histidine structure of the fusion peptide (scheme 2), where two vacant coordination sites on the nickel ions are exposed and enable strong coordination with the electrondonor containing pouch in the poly-histidine sequences. 
Aqueous nickel-nitrilotriacetate modified $\mathrm{Fe}_{3} \mathrm{O}_{4}-\mathrm{NH}_{3}^{+}$nanoparticles

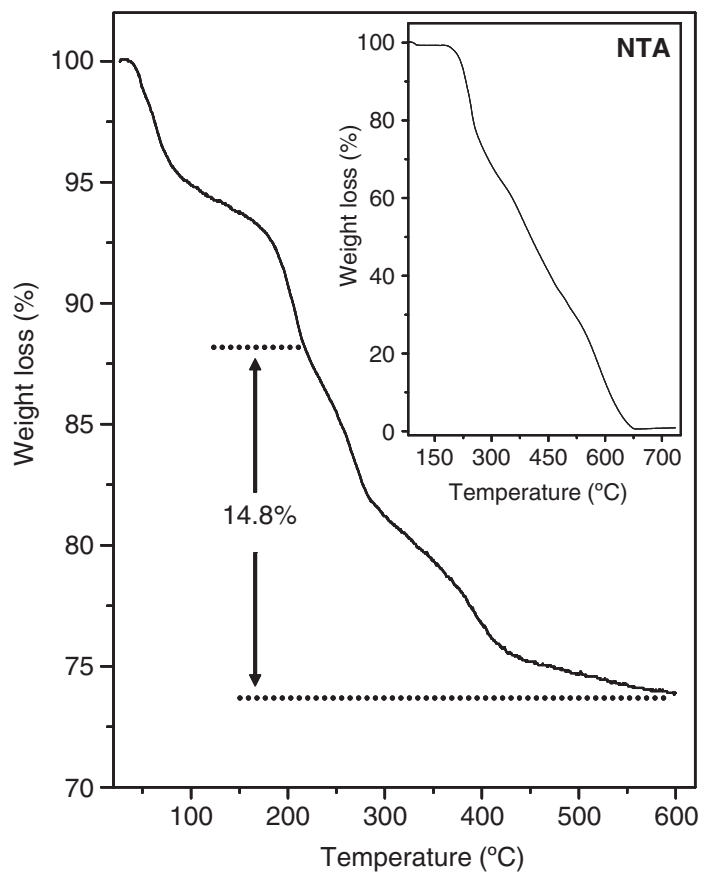

Figure 2. The thermogravimetric analysis (TGA) curve for $\mathrm{Fe}_{3} \mathrm{O}_{4}$-NTA (inset: TGA behaviour from pure NTA molecules).

TGA analysis was carried out and the quantity of the NTA conjugation was evaluated from the weight lost in the TGA curve. The TGA profile shows that the weight loss occurs in steps, with total loss of $26 \%$ up to $600^{\circ} \mathrm{C}$ (figure 2). The initial weight loss of $\sim 6.5 \%$ can be attributed to the elimination of physical and chemical adsorbed $\mathrm{H}_{2} \mathrm{O}$ between 30 and $160^{\circ} \mathrm{C}$. The weight loss of $\sim 4.7 \%$ in the temperature range $160-210^{\circ} \mathrm{C}$ is assigned as the decomposition of the linker, glutaraldehyde. The glutaraldehyde molecules have been found to decompose at a temperature of $\sim 188^{\circ} \mathrm{C}$ [25] A pronounced weight loss step is found in the temperature range from $210^{\circ} \mathrm{C}$ up to $600^{\circ} \mathrm{C}$, which can be ascribed to the decomposition of the NTA molecules and is consistent with the TGA behavior of the pure NTA molecules (inset in figure 2). It is evaluated that a weight loss of $\sim 14.8 \%$ is determined and approximately 340 NTA molecules are tagged on a $\mathrm{Fe}_{3} \mathrm{O}_{4}$ nanoparticle.

The adsorption of $\mathrm{Ni}^{2+}$ onto $\mathrm{Fe}_{3} \mathrm{O}_{4}$-NTA was monitored as a function of incubation time. The ratio of $\mathrm{Ni}^{2+}$ and $\mathrm{Fe}_{3} \mathrm{O}_{4}$ was calculated based on the analysis of atomic absorption. Adsorption studies of nickel ions indicate that the ratio of $\mathrm{Ni}^{2+}$ binding on the $\mathrm{Fe}_{3} \mathrm{O}_{4}$-NTA nanoparticles rapidly increased from 0 to 80 over the initial incubation time of $2 \mathrm{~h}$. Then the adsorption ratio gradually rose to $\sim 140$ when the incubation was extended for $8 \mathrm{~h}$ (figure 3). After incubation for $10 \mathrm{~h}$, the intensity increased only slightly to $\sim 154$, which suggests that the binding capacity of $\mathrm{Fe}_{3} \mathrm{O}_{4}$-NTA should have reached saturation for the nickel ions.

\subsection{Purification of 6-His tagged recombinant proteins from bacteria lysate}

The binding capacity of the $\mathrm{Fe}_{3} \mathrm{O}_{4}$-NTA-Ni to 6-His tagged proteins was evaluated by using purified recombinant 6 -His

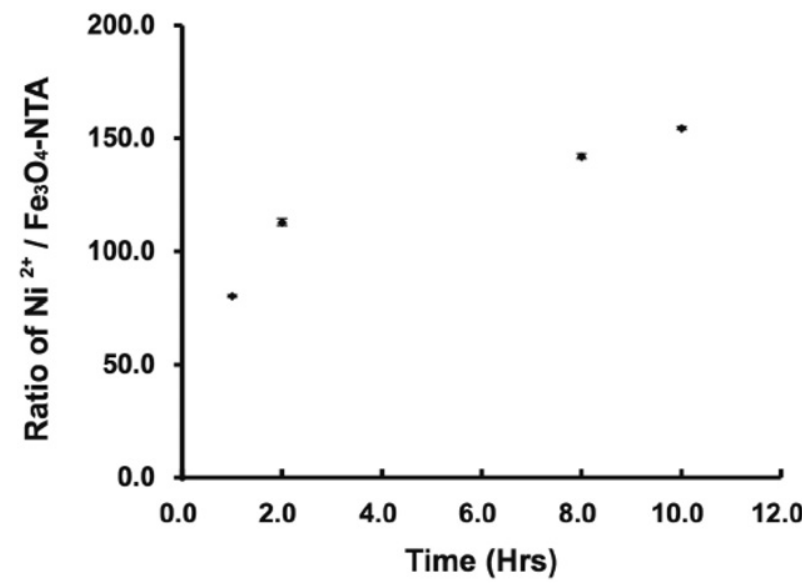

Figure 3. Adsorption of nickel ions onto the $\mathrm{Fe}_{3} \mathrm{O}_{4}$-NTA nanoparticles as a function of incubation time between $\mathrm{NiSO}_{4}$ and $\mathrm{Fe}_{3} \mathrm{O}_{4}$-NTA.

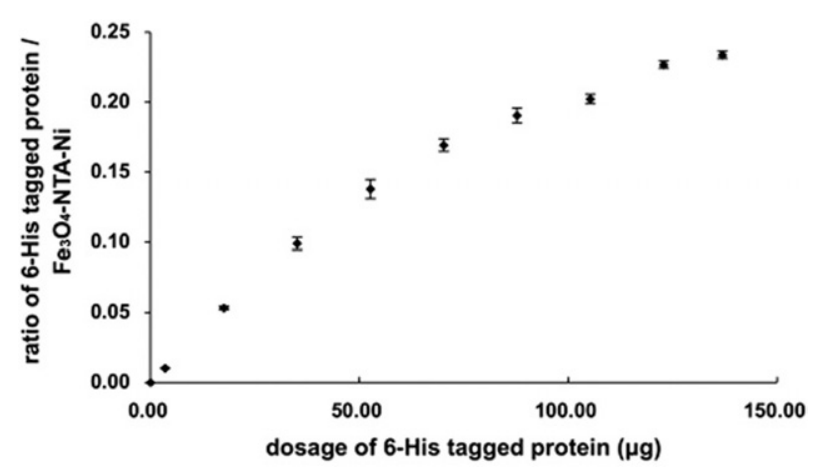

Figure 4. The ratio of protein to $\mathrm{Fe}_{3} \mathrm{O}_{4}-\mathrm{NTA}-\mathrm{Ni}$ nanoparticles as a function of protein dosage. The total amount of the nanoparticles remained constant throughout the experiments $\left(32 \mathrm{mg}^{-1} \mathrm{ml}^{-1}\right.$ for $\mathrm{Fe}_{3} \mathrm{O}_{4}-\mathrm{NTA}-\mathrm{Ni}$ ).

tagged V344A mutant streptopain (42 kDa). Figure 4 shows that the protein binding efficiency gradually increased from the initial 0.01 to 0.23 (mg protein per mg $\mathrm{Fe}_{3} \mathrm{O}_{4}$-NTA$\mathrm{Ni}$ ). In these results, we found that the binding capacity of $\mathrm{Fe}_{3} \mathrm{O}_{4}-\mathrm{NTA}-\mathrm{Ni}$ nanoparticles is about 45 times higher than that of the commercial magnetic microbeads (Dynabead ${ }^{\circledR}$, 5-12 $\mu \mathrm{g}$ protein per $\mathrm{mg}$ bead), which indicates that the high surface/volume ratio of the nanoparticles may contribute to the higher efficiency. The optimal performance of the protein release was investigated by modulation of imidazole concentration in elution buffer. As shown in figure 5, the eluted efficiency reaches a plateau as the imidazole concentration approaches $300 \mathrm{mM}$. When the imidazole concentration in the elution buffer is higher than $500 \mathrm{mM}$, the excess imidozole would interfere with the spectrophotometric analysis of the protein. Thereafter, a $400 \mathrm{mM}$ of imidazole concentration is chosen for the following protein purification.

As the synthesized $\mathrm{Fe}_{3} \mathrm{O}_{4}$-NTA-Ni nanoparticles are able to bind and release purified 6-His-tagged peptides, we further evaluate the direct protein purification from bacteria expressing mutant streptopain with 6-His tagged on the $\mathrm{N}$-terminus. The process is illustrated in scheme 1. Figure 6(a) shows the SDS-PAGE analysis of the products from each fraction of the 


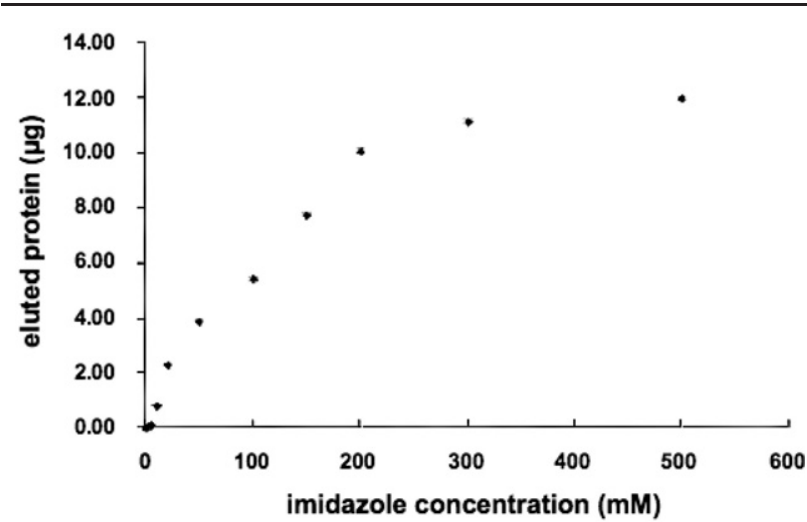

Figure 5. The 6-His protein desorption as a function of imidazole concentration.

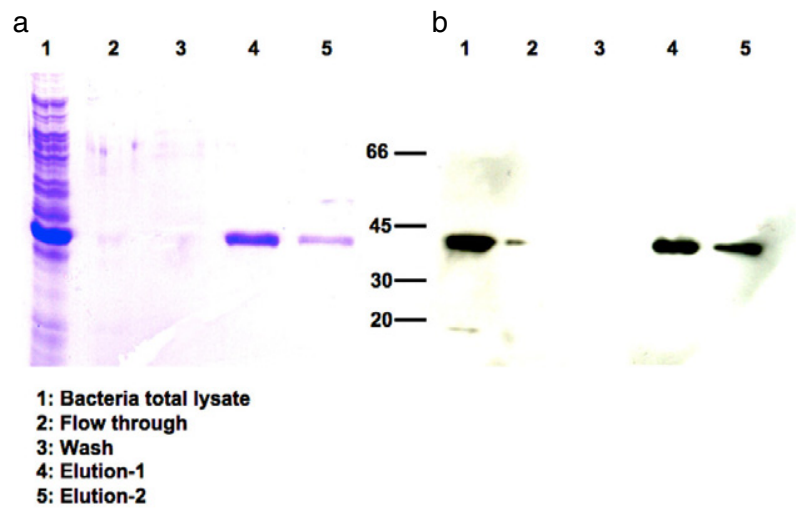

Figure 6. (a) SDS-PAGE analysis reveals a specific binding of the $\mathrm{Fe}_{3} \mathrm{O}_{4}$-NTA-Ni nanoparticles to the streptopain mutant protein with 6-His tag from a crude bacteria lysate following magnetic force separation. (b) Western blot analysis probed by anti-6-His monoclonal antibody shows a specific high yield of the protein following the magnetic purification protocol.

elution process. A prominent band at a molecular weight of $42 \mathrm{KDa}$ (the molecular weight of streptopain) was observed in the original bacteria total lysate (lane 1), and the first (lane 4) and second elusion (lane 5), but was not detectable in the pass through (lane 2) and wash buffer (lane 3) collections. In addition, Western blot analysis also demonstrated a single band with the correct molecular weight of the protein. Significant protein recovery without evidence of degradation and nonspecific binding was observed (figure 6(b)). Furthermore, thermal stability of the $\mathrm{Fe}_{3} \mathrm{O}_{4}-\mathrm{NTA}-\mathrm{Ni}$ nanoparticles was observed, as they can be stored at a temperature of $50{ }^{\circ} \mathrm{C}$ for more than one month and still retain their functionality.

Since the presented iron oxide particles are fabricated in an aqueous environment, a similar idea for modulated design of SAM on nanoparticles such as conjugation of glutathione for the purification of GST-fusion proteins could be achieved and is currently under investigation.

\subsection{The RGD-4C-6-His magnetite nanoparticle conjugate and in vitro targeting analysis}

The specific affinity between 6-His-tagged peptides and NTA$\mathrm{Ni}$ establishes a platform to engineer precisely the oriented biomolecules on nanoparticle surfaces, where the conventional chemical crosslinking strategies usually result in a randomized orientation in biomolecules. This enables enhanced in vivo targeting for the molecular diagnosis or therapeutic applications.

For further in vitro or in vivo studies, a primary evaluation of the hemocompatibility was conducted by hemolysis assay for $\mathrm{Fe}_{3} \mathrm{O}_{4}$-NTA-Ni. The hemolysis assay shows no detectable hemolysis activity of the nanoparticles at all dosages ranging from $0.1 \mathrm{mM}$ to $10 \mathrm{mM}$ particle concentrations, as seen in figure 7(a). In addition, the potential hemolysis behaviour was compared to the positive $(0.1 \%$ sodium carbonate) and the negative control (normal saline) after incubation for 1,2 and $4 \mathrm{~h}$. As shown in figure 7(b), all test dosages present no significant hemolysis ( $<1 \%$ of the control).

Cancer cells and their neoangiogenic blood vessels usually present altered expression of cell adhesion molecules including specific types of integrins [26]. Cyclic RGD-4C peptide presents specific affinity to $\alpha_{\mathrm{v}} \beta_{3}$ and $\alpha_{3} \beta_{5}$ integrins that often selectively express in tumor tissues. Enhanced tumor gene therapy has been demonstrated using RGD-4C modified adenovirus [27]. This peptide has also been applied for the imaging and monitoring of tumor angiogenesis [28, 29]. Herein, we design a fusion peptide consisting of a cyclic a.

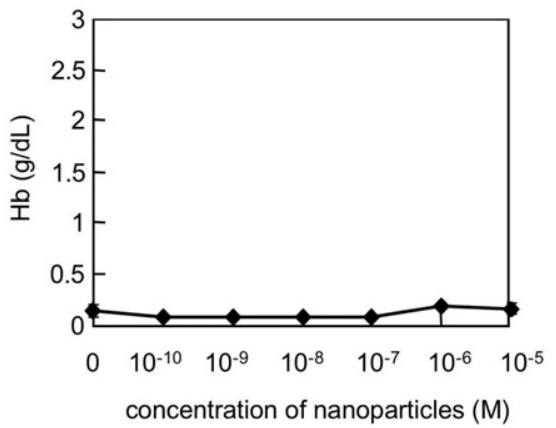

b.

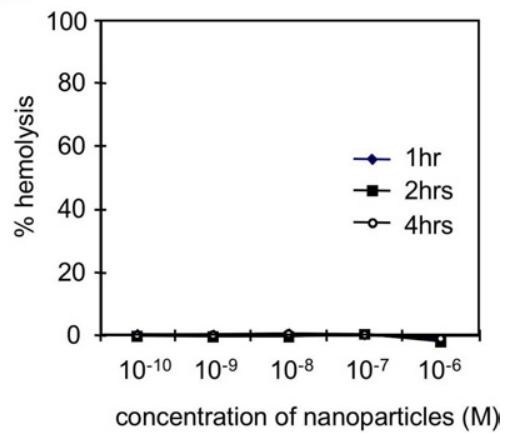

Figure 7. (a) Hemocompatibility assay of the as-synthesized $\mathrm{Fe}_{3} \mathrm{O}_{4}$-NTA-Ni nanoparticles performed in freshly prepared human whole blood by measuring the presence of hemoglobin in the serum derived from lysed red blood cells upon exposure to the nanoparticles. No significant hemolysis activity is detected in all dosages compared to the control set of the phosphate buffer saline control $(0.0 \mathrm{M}$ particle concentration).

(b) The $\mathrm{Fe}_{3} \mathrm{O}_{4}$-NTA-Ni nanoparticles show no significant hemolysis detected during time periods of 1, 2 and $4 \mathrm{~h}$ of exposure in all test dosages, with reference to the positive control ( $0.1 \%$ sodium carbonate). 


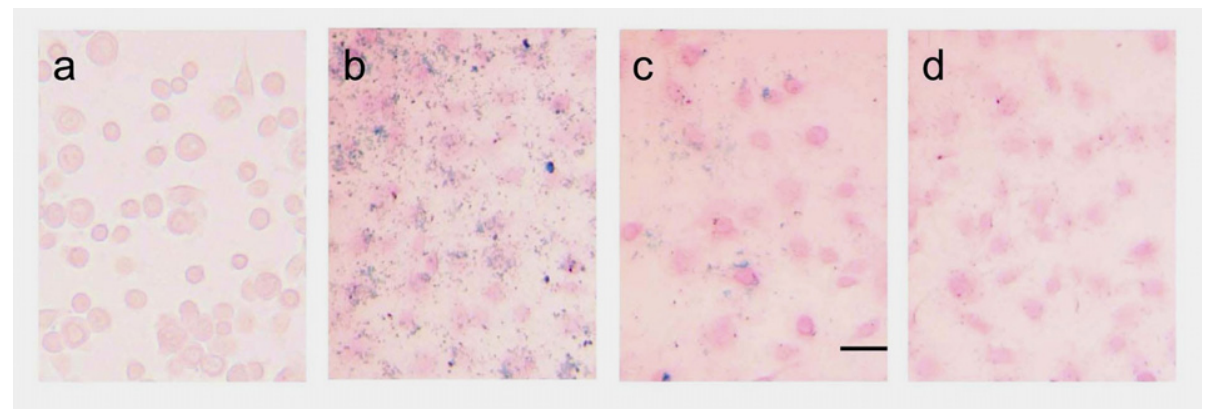

Figure 8. The RGD4C-6His cyclic peptides self-assembled on $\mathrm{Fe}_{3} \mathrm{O}_{4}$-NTA-Ni nanoparticles present no detectable binding to the normal oral keratinocytes (a) compared to the oral cancer cell $\mathrm{HCDB} 1$ (b), as revealed by iron staining (blue colour). $\mathrm{Fe}_{3} \mathrm{O}_{4}$ nanoparticles with traditional chemical crosslinking of the RGD4C-6His cyclic peptides (c) show significantly less efficient targeting than (b). Nanoparticles alone fail to target HCDB1 cells and present only background staining (d). (Scale bar $=20 \mu \mathrm{m}$.)

RGD-4C domain, a 6 glycine spacer and a 6-His tag on the C-terminal end. Oral cancer cells (HCDB-1) [24] expressing a high level of $\alpha_{\mathrm{v}} \beta_{3}$ integrin compared to the normal oral keratinocytes (HNOK) are used for the in vitro targeting. Nanoparticles were incubated with the peptides before incubation with either fixed or living cells cultured on a chamber slide. The results show a prominent selectively targeting of the nanoparticle-RGD-4C-6-His complex to the cancer cells (figure 8(b)), while only little non-specific staining was detectable in the normal keratinocytes (figure 8(a)). In a control experiment without molecular orientation, we synthesized RGD-4C surface modified nanoparticles using a simply applied chemical crosslinking method using 1-ethyl3-(3-dimethylaminopropyl)-carbodiimide (EDC) to form a covalent bond between the amine group on the nanoparticle surface and the carboxyl group on the peptide. As shown in figure $8(\mathrm{c})$, the randomly crosslinking RGD-4C without molecular orientation revealed significantly less efficient targeting than the self-assembled RGD-4C-nanoparticles in figure $8(\mathrm{~b})$. Finally, figure 8(d) shows that nanoparticles alone failed to target HCDB1 cells and showed only background staining. These results suggest the advantage of the selfassembly strategy through the 'key' (NTA-Ni) to 'key lock' (6His tag on the targeting biomolecule warhead) concept, which provides enhanced targeting efficiency due to the precisely controlled biomolecular orientation on the nanoparticle.

\section{Conclusions}

We have demonstrated the aqueous synthesis of $\mathrm{Fe}_{3} \mathrm{O}_{4}-\mathrm{NH}_{3}^{+}$ nanoparticles modified with NTA-Ni. The modified nanoparticles show high efficiency and specificity for the rapid purification of 6-His tagged proteins and present no hemolysis between concentrations of $10^{-5}-10^{-10} \mathrm{M}$ as well as satisfactory biocompatibility for in vitro studies. In vivo targeting assay showed significantly enhanced tumor cell targeting compared to random chemical conjugation. These results indicate that the as-synthesized iron oxide nanoparticles may hold great potential as universal modularly designed functionalized carriers for magnetite field guided biomolecule purification, magnetic force driven drug delivery nanovehicles, and molecular imaging agents, which present the advantages of modularly designed particle and targeting moiety with guaranteed biomolecule orientation. The platform could be applied further to a broad spectrum of affinity-based proteinprotein interaction biosensing.

\section{Acknowledgments}

We thank Professor Woei-Jer Chaung and Pei-Ju Wang for kindly providing us with the 6-his tagged streptopain mutant peptide to evaluate the protein purification efficiency of the $\mathrm{Ni}$ $\mathrm{NTA}-\mathrm{Fe}_{3} \mathrm{O}_{4}$ nanoparticle conjugates. This study was supported by the National Science Council of Taiwan.

\section{References}

[1] Zaric S D, Popovic D M and Knapp E W 2000 Chem. Eur. J. 63935

[2] Rosenzweig A C, Huffman D L, Hou M Y, Wernimont A K, Pufahl R A and O'Halloran T V 1999 Struct. Fold Des. 7605

[3] Ha Y, Shi D S, Small G W, Theil E C and Allewell N M 1999 J. Biol. Inorg. Chem. 4243

[4] Hutchens T W and Yip T T 1991 J. Chromatogr. 5361

[5] Kumar A, Galaev I Y and Mattiasson B 1998 Biotechnol. Bioeng. 59695

[6] Chen H T, Legault P, Glushka J, Omichinski J G and Scott R A 2000 Protein Sci. 91743

[7] Teng H and Grubmeyer C 1999 Biochemistry 387363

[8] Bhattacharyya R, Saha R P, Samanta U and Chakrabarti P 2003 J. Proteome. Res. 2255

[9] Delaney S J, Hayward D C, Barleben F, Fischbach K F and Miklos G L 1991 Proc. Natl Acad. Sci. USA 887214

[10] Cox J H, Ivanyi J, Young D B, Lamb J R, Syred A D and Francis M J 1998 Eur. J. Immunol. 182015

[11] Joyce S, Sun R and Nathenson S G 1992 Biochem. Biophys. Res. Commun. 1861449

[12] Peterson E M, Cheng X, Qu Z H and DelaMaza L M 1996 Mol. Immunol. 33335

[13] Focher F, Spadari S and Maga G 2003 Curr. Drug. Targets Infect. Disord. 341

[14] Juang R S and Wang Y C 2003 Water Res. 37845

[15] Phan T C, Nowak K J, Akkari P A, Zheng M H and Xu J 2003 Protein Expr. Purif. 29284

[16] Hainfeld J F, Liu W Q, Halsey C M R, Freimuth P and Powell R D 1999 J. Struct. Biol. 127185

[17] Buchel C, Morris E, Orlova E and Barber J 2001 J. Mol. Biol. 312371

[18] Abad J M, Mertens S F L, Pita M, Fernandez V M and Schiffrin D J 2005 J. Am. Chem. Soc. 1275689 
[19] Gu H, Ho P L, Tsang K W T, Wang L and Xu B 2003 J. Am. Chem. Soc. 12515702

[20] Yeh C S, Cheng F Y, Shieh D B and Wu C L 2004 ROC Patent Specification 202070, German Patent submitted

[21] Shieh D B, Cheng F Y, Su C-H, Yeh C S, Wu M T, Wu Y N, Tsai C Y, Wu C L, Chen D H and Chou C H 2005 Biomaterials 267183

[22] Lutz S, Christian D and Tampe R 1994 J. Am. Chem. Soc. 1168485

[23] Chen C Y, Luo S C, Kuo C F, Lin Y S, Wu J J, Lin M T, Liu C C, Jeng W Y and Chuang W J 2003 J. Biol. Chem. 27817336
[24] Lin S C, Chang K W, Chang C S, Yu S Y, Chao S Y and Wong Y K 2000 Proc. Natl Sci. Counc. Rep. China B 24129

[25] Lide D R 2000 CRC Handbook of Chemistry and Physics 81th edn (London: CRC Press)

[26] Zitzmann S, Ehemann V and Schwab M 2002 Cancer Res. 62 5139

[27] Bauerschmitz G J et al 2002 Cancer Res. 621266

[28] Su Z F, Liu G, Gupta S, Zhu Z, Rusckowski M and Hnatowich D J 2002 Bioconjug. Chem. 13561

[29] Chen X, Sievers E, Hou Y, Park R, Tohme M, Bart R, Bremner R, Bading J R and Conti P S 2005 Neoplasia 7271 